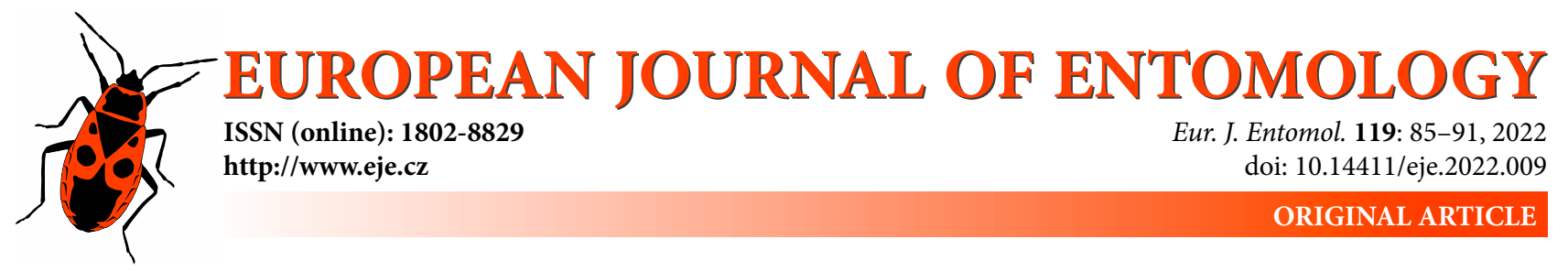

\title{
Presence after three decades of red wood ants (Formica rufa group; Hymenoptera: Formicidae) in forests in an agricultural landscape
}

\author{
HARRY J.M. VAN BUGGENUM \\ Rijdtstraat 118, 6114 AM Susteren, The Netherlands; e-mail: hvanbuggenum@gmail.com
}

Key words. Mound-building ants, long term monitoring, fragmented habitat, occupancy, influence of environment, forest management, The Netherlands

\begin{abstract}
Conducting a repeat study of the presence of mound-building red wood ants (Formica rufa group) after a period of 30 years has rarely been done in Europe. From 1990 to 2020 such a study was done in an intensively used agricultural landscape with fragments of forest in the South-Eastern part of The Netherlands. In 1990, 280 nest mounds of three species of red wood ants and a hybrid were found in the forests and along forest edges. The highest occupancy was in forests of $>25$ ha. The connectivity between the forest fragments mainly determined their presence. In 2020, only 160 nest mounds were found. The development of the colonies differed for Formica polyctena Förster, 1850 (slight decrease), F. rufa Linnaeus, 1761 (substantial increase) and $F$. pratensis Retzius, 1783 (strong decrease). The differences between the species in this highly fragmented landscape may be due to differences in their colonization strategies of either nest splitting or producing swarms of young queens. Furthermore, the analyses show that the type of environment (in a forest or along a forest edge) determines the probability of extinction or settlement. There is a need to undertake management measures to prevent the extinction of species of red wood ants in the area studied. These measures include creating small clearings in dense forests, reducing shading due to overgrowing shrubs or herbaceous plants, and creating buffer zones around intensively manured fields. More long-term monitoring is needed in Europe to compare the circumstances in different regions, detect trends and evaluate the effects of protection measures.
\end{abstract}

\section{INTRODUCTION}

In recent decades, the number and distribution of many plants and animals have declined sharply in artificial landscapes, not only in The Netherlands but also elsewhere. As important causes, loss and fragmentation of habitat, pollution, climate change, invasive alien species and numerous other factors are mentioned as causes of recent declines (Sánchez-Bayoa \& Wyckhuys, 2019; Jactel et al., 2020; Wagner et al., 2021). For several groups of insects, such declines are reported for a great diversity of insect in terms of both species and biomass (Hallmann et al., 2017). The question is, which species are more vulnerable to human influences and whether further decline can be prevented. The present research is limited to a few mound-building species of red wood ants (Genus: Formica; Subgenus: Formica) because their nests are relatively easy to find. There are indications that several species have decreased locally in Europe.

In The Netherlands, there are four species of the Formica rufa group: F. polyctena, F. rufa, F. pratensis and $F$. truncorum Fabricius, 1804 (Boer, 2010), and F. truncorum is limited to one metapopulation in the province of Overijssel (Mabelis \& Chardon, 2006). The other species can be found throughout this country. F. rufa and F. polyctena are not yet wholly separated evolutionarily and can hybridize resulting in $F$. rufa $\times$ polyctena (Seifert, 1991; Goropashnaya et al., 2004; Boer, 2010; Seifert et al., 2010).

Red wood ants play a significant role in keeping an ecological balance and combating pests in forests (Véle \& Modlinger, 2016). Therefore, it is important to know where colonies occur and whether they can survive. However, long-term population studies are rarely conducted. Robinson \& Robinson (2008) report the presence of $F$. rufa after 20 years in a woody nature reserve in England. Almost half of the old nests were still inhabited and due to new establishments, the total number of nest mounds was still nearly the same as previously. Dekoninck et al. (2010) show that after 20 years, the West Flemish (Belgium) populations of $F$. rufa and $F$. polyctena have declined by more than $50 \%$. This was due to overgrowth by shrubs, the closing of the canopy, adjacent agricultural land use, urbanization, and recreation. After 28 years, Mabelis \& Korczyńska (2016) report a sharp decline in $F$. rufa and $F$. polyctena in the Twente region (The Netherlands) due to the strong negative influence of the presence of intensive agricultural next to forest edges. These three studies motivated the repeat of an old study of 1990 in the province of Limburg (The Netherlands). 
The main research questions addressed in this study are: (1) what changes in forest occupancy and distribution of red wood ants had occurred after 30 years, (2) did nest number and nest size change during that period, (3) what factors are likely to have caused the changes?

\section{MATERIALS AND METHODS}

\section{Study area characteristics}

The study area is in the central part of the province of Limburg (The Netherlands), east of the River Meuse (center $51^{\circ} 06^{\prime} 38.72^{\prime \prime} \mathrm{N}, 5^{\circ} 56^{\prime} 39.94^{\prime \prime} \mathrm{E} ; 30-50 \mathrm{~m}$ a.s.l.). The area covers about 3600 ha. From the 16th century onwards, this area was almost entirely deforested by logging and overgrazing by cattle (Coenen, 2006). In the second half of the 19th century, many fields were planted with coniferous trees (especially Pinus sylvestris L. and Picea abies (L.) H. Karst). The wood of which was used as pit props in the coal mines in nearby South Limburg. Furthermore, forest plots were planted with Quercus robur L., which served mainly as coppice wood. As a result, of several decades of planting or spontaneous colonization by Larix species, Quercus rubra L., Betula pendula Roth, Fagus sylvatica L. and Carpinus betulus L. plots of trees developed in this area, which are mostly now aged 130-170 years (Van der Leest et al., 2006). Most trees are younger due to wood harvesting. The shrub layer developed spontaneously due to colonization by indigenous species like Sambucus nigra L., Sorbus aucuparia L., Rubus species, Rhamnus frangula L. and Ilex aquifolium L. The herbaceous plant layer in the forests is generally poor in species and includes species such as Deschampsia flexuosa (L.) Trin., Dryopteris species and Pteridium aquilinum (L.) Kuhn. Since the beginning of the 20th century, all areas with heather, marshes and several plots of forest were used for agriculture and animal farming. In 1990, the area studied consisted of some large and small forests and isolated fragments of forest with a total area of about 900 ha. The nest mounds of the red wood ants were in or on the edges of these forests. The rest of the area is mainly agricultural land. The area studied is bisected by streams, roads and a railway line. Locally there are small nature reserves with extensive grassland, several farms and recreation parks. The forests are all growing in weakly loamy fine sand, or coarse sand. In some areas, gravel occurs in the upper subsoil. Under the forests, the groundwater levels are generally deeper than $1.80 \mathrm{~m}$ (BIS Nederland, 2021).

\section{Forests and forest fragments}

Based on the methods of Mabelis \& Chardon (2006); Seifert et al. (2010) and Mabelis \& Korczyńska (2016), the area studied was divided into forests and forest fragments. The latter includes connected linear woody landscape elements or barriers between forest fragments due to paved infrastructure, waterways, or intensive agricultural land use. A total of 82 forests or forest fragments were distinguished. For some analyses, they were put together into three classes: (class 1$)<5$ ha, (class 2$) 5-25$ ha and (class 3) $25-150 \mathrm{ha}$.

\section{Fieldwork}

The first field study was in 1989-1990. A total of $180 \mathrm{~km}$ of forest edges, $90 \mathrm{~km}$ (mostly unpaved) forest roads and logged area were surveyed in May-September for the presence of nest mounds. The second study was carried out in 2019-2020. In the intervening 30 years, the area of forest and land use changed only slightly, so the size and method of field research was almost the same as in the first period.

\section{Species of red wood ants, colonies and nest mound size}

Ten workers from one or more nests of a colony were examined for the presence of hair on their eyes, on the underside of their heads and on the pronotum in order to determine the species. In addition, whether a colony was monodomous or polydomous was determined (Gösswald, 1989; Seifert, 1996; Ellis \& Robinson, 2014). The hybrid $F$. rufa $\times$ polyctena was distinguished based on it having characteristics intermediate between the two-parent species (Seifert, 1991). The surest method of determining a hybrid, combines this with genetic research (Seifert et al., 2010), which was not the case in this study.

Several methods can be used distinguish individual colonies of species at a specific forest location (Ellis et al., 2017). In the present research, clustering was based on distance. If two nests within one forest or forest fragment were less than $150 \mathrm{~m}$ apart, they were counted as the same colony. This distance is based on studies on territory size and average range of workers (e.g., Mabelis, 2002; Dekoninck et al., 2010; Boer et al., 2018).

For each nest mound, the radius (r) at the bottom of the mound, the height (h) and various environmental variables were recorded as characteristics. The nest mound area was calculated as $\pi * r^{2}$. The volume of the nest mound was calculated using the formula for half an ellipsoid: volume $=2 / 3 * \pi * r^{2} * h$.

\section{Environmental variables, connectivity and nest location}

For all of the 82 forests, the forest area and forest edge length were included as environmental variables (Dekoninck et al., 2010; Mabelis \& Korczyńska, 2016). As a measure of connectivity between the forests, three parameters were measured: (1) the average distance of the edge of a forest to edges of the three nearest forests, (2) the distance of the edge of a forest to the nearest nest mound in another forest, (3) the incidence function model, in which the contributions of all the surrounding occupied patches within dispersal distance of flying queens are taken into account in determining their probability of colonization (Hanski, 1994; Mabelis \& Chardon, 2006). For this, the distance over which flying Formica queens can disperse is set at two kilometres, since most of them remain within this distance (Mabelis \& Chardon, 2006; Boer, 2010; Vitikainen et al., 2015). The topographical analyses were carried out using the QGIS 3.16 program (QGIS, 2021). In 1990, the location of a every nest mound was recorded: (1) in a forest, (2) at the edge of a forest, adjacent to an intensively used agricultural field, or (3) at the edge of a forest, with adjacent extensive land use (e.g., a road verge or nature reserve). In 2020, whether these nests were still present at the same localities was recorded. A displacement up to $50 \mathrm{~m}$ from the old location was also considered as being present.

\section{Data analyses}

The Shapiro-Wilk test was used to test data for normal distribution. To comply with normality, the natural logarithm transformation was used if necessary. McNemar's test was used for paired comparisons of presence-absence of a species in the 82 forests in 1990 and 2020. To compare environmental variables, the Wilcoxon test or Pearson test was used. Frequency distributions were tested using either chi-square tests or Fisher's Exact tests.

Generalized linear models (GLMs) were compiled for each species and each period. Presence-absence of a species in a forest was used as a dependent response variable. Two forest characteristics (area and edge length) and three connectivity characteristics were added as independent predictor variables. Starting with a full model, stepwise backward regression, and Akaike information criteria (Burnham \& Anderson, 2004), were used to the select final GLMs. The variance of the final models is indicated by 

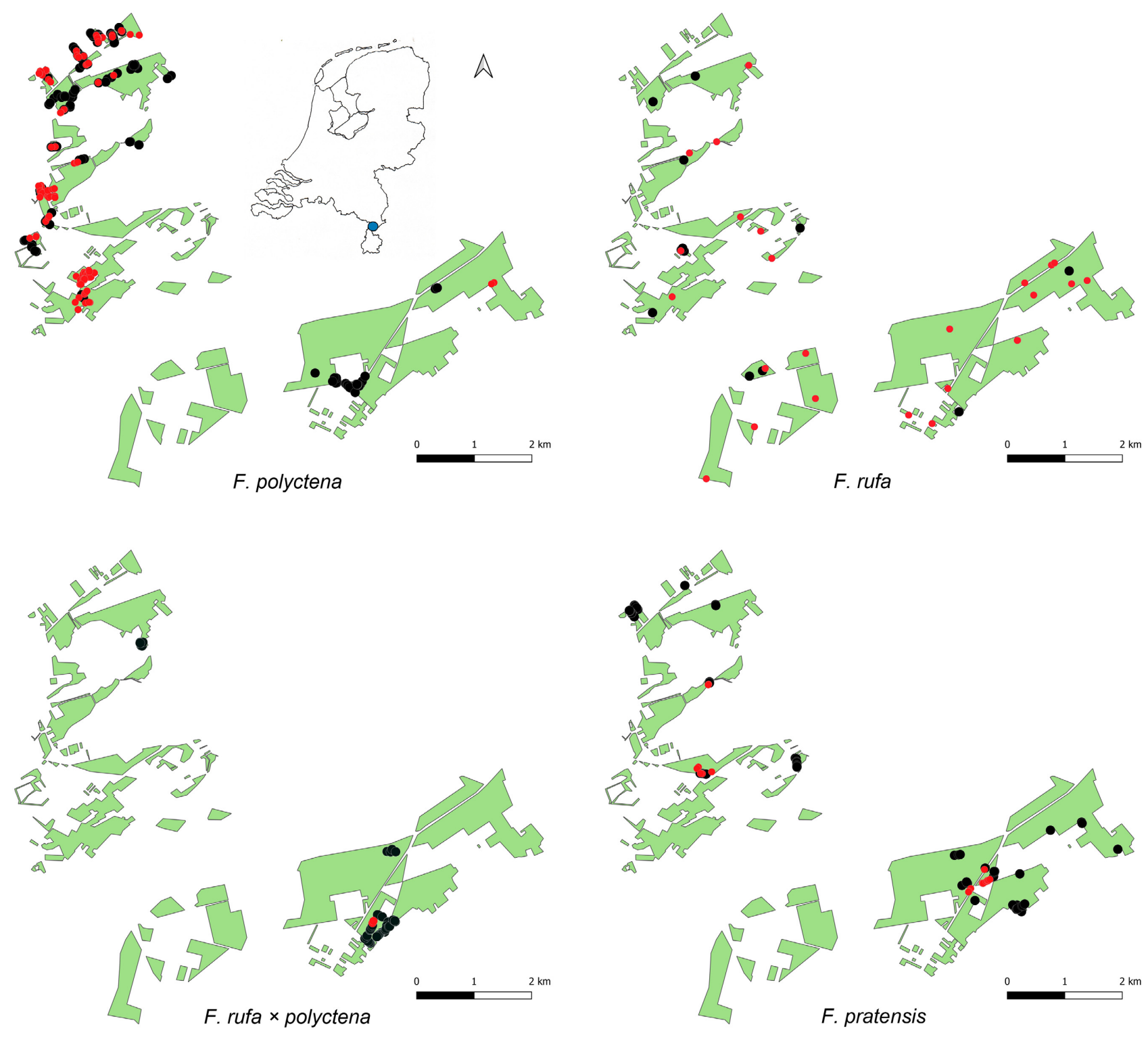

Fig. 1. Location of the area studied, forests, forest fragments and location of the nest mounds in 1990 (black) and 2020 (red) in the central part of the province of Limburg (The Netherlands).

the pseudo- $\mathrm{R}^{2}$ of Nagelkerke (Nagelkerke, 1991). All statistical calculations were done using program $\mathrm{R}$ - version 4.0.5 and appropriate packages in R-Studio ( $\mathrm{R}$ Core Team, 2021). Alpha was set at 0.05 for all statistical tests.

\section{RESULTS}

\section{Presence in forests}

The location of nest mounds in the forests is shown schematically in Fig. 1. The percentages of forests occupied in 1990 and 2020 is shown in Table 1. In 1990, at least one species of red wood ant of the $F$. rufa group was found in $37 \%$ of the 82 forests and in 2020 it was $43 \%$. In 1990, F. polyctena had the highest presence and in 2020 it was $F$. rufa. Only the increase in F. rufa was significant (McNemar's test: $\chi^{2}=4.50, \mathrm{DF}=1, \mathrm{p}=0.03$ ).

Presence increased from small to large forests, which was the case for all species in both periods (Table 1). The results recorded in 2020 were not significantly different from those recorded in 1990 (Fisher's Exact test; $\mathrm{p}>0.05$ ). It is noticeable that in 2020 all forests of $>25$ ha were colonized by at least one species of red wood ant.

There was a slight decline in forest occupancy by $F$. polyctena from 1990 to 2020 . This decline occurred mainly in small forest fragments of $<5$ ha. F. rufa increased in all three forest size classes. The increase was most significant in forest class 25-150 ha. In 1990, the hybrid F. rufa $\times$ polyctena was recorded in three forests of $>25$ ha. Of these, only one colony was found again in 2020. The forest occupancy by $F$. pratensis declined sharply. Colonies disappeared from all forest classes and no new sites were recorded elsewhere.

\section{Variables and models}

The main characteristics of the environmental and connectivity variables recorded for the 82 different forests are shown in Table 2. None of the variables were distributed normally (Shapiro-Wilk test; $\mathrm{p}<0.05$ ). For $F$. polyctena 
Table 1. The percentage of forests occupied per class per species for 1990 and 2020. In parentheses the number of forests populated in both years, the number only populated in 1990 and the number only populated in 2020.

\begin{tabular}{|c|c|c|c|c|c|c|c|c|}
\hline \multirow{2}{*}{ Species } & \multicolumn{2}{|c|}{ All forests $(n=82)$} & \multicolumn{2}{|c|}{ Forest $<5$ ha $(n=55)$} & \multicolumn{2}{|c|}{ Forest $5-25$ ha $(n=17)$} & \multicolumn{2}{|c|}{ Forest $25-150$ ha $(n=10)$} \\
\hline & year 1990 & year 2020 & year 1990 & year 2020 & year 1990 & year 2020 & year 1990 & year 2020 \\
\hline F. polyc & 24.4 & 20.7 & 21.8 & $14.5(7-5-1)$ & 23.5 & $29.4(4-0-1)$ & 40.0 & $40.0(3-1-1)$ \\
\hline F. rufa & 12.2 & 24.4 & 7.2 & $9.1(1-3-4)$ & 17.6 & $35.2(2-1-4)$ & 30.0 & $90.0(3-0-0)$ \\
\hline F. rufa $\times$ polyctena & 3.7 & 1.2 & - & - & - & - & 30.0 & $10.0(1-2-0)$ \\
\hline F. pratensis & 11 & 4.9 & 1.8 & $-(0-1-0)$ & 17.6 & $11.7(2-1-0)$ & 50.0 & $20.0(2-3-0)$ \\
\hline Formica rufa-group & 36.6 & 42.7 & 30.9 & 23.6 & 41.2 & 70.5 & 60.0 & 100.0 \\
\hline
\end{tabular}

and $F$. pratensis the median distance from a forest to the nearest nest was significantly higher in 2020 than in 1990 (Wilcoxon $\mathrm{W}=2107, \mathrm{Z}=2.82, \mathrm{p}<0.005$; $\mathrm{W}=2522, \mathrm{Z}=$ $3.80, \mathrm{p}<0.001)$. For $F$. rufa, this difference was not significant (Wilcoxon $\mathrm{W}=1670, \mathrm{Z}=1.07, \mathrm{p}=0.282$ ).

The results of the generalized logistic regression models (GLMs) are shown in Table 3. Forest area and length of forest edge were strongly correlated (Pearson's $r=0.96 ; p$ $<0.001)$. Because edge length yielded better models, forest area was omitted. For the hybrid $F$. rufa $\times$ polyctena, there was not enough data to make a model. Except in one model, the presence-absence of all species was positively correlated with the incident function model in both periods. The model for $F$. polyctena selected for distance of a forest to a nest mound as a significant connectivity parameter in 2020. Forest edge length appeared to be a significant predictor for the presence of $F$. polyctena and $F$. rufa in 2020. Four of the six models had a relatively high explained variance of more than $50 \%$.

\section{Nest mound locations}

A total of 280 nest mounds were found in 1990 and 162 in 2020. For F. polyctena and F. rufa, the distribution did not differ significantly from an equal distribution at the three locations (Table 4). Opposingly, this was the case for the hybrid in 1990. Nest mounds were most common in forests $\left(\chi^{2}=13.32, \mathrm{DF}=2, \mathrm{p}<0.01\right)$. F. pratensis was most common along forest edges with adjacent intensive agricultural land use in $1990\left(\chi^{2}=18.08, D F=2, p<0.001\right)$ and along forest edge with adjacent extensive land use in $2020\left(\chi^{2}=12.09, \mathrm{DF}=2, \mathrm{p}<0.01\right)$.

The number of nest mounds in 1990 that still existed in 2020 differed for location and species (Table 4). In forests and forest edges along intensively used fields, only $0 \%-21 \%$ still existed after 30 years. This percentage was higher along forest edges with extensive adjacent land use (F. polyctena: 35\%; F. pratensis: 73\%).

\section{Population characteristics}

In 1990 and 2020, several population characteristics differ for each species (Table 5). F. polyctena declined by $21 \%-35 \%$ in the number of colonies, number of nest mounds and total area of the nest mounds. The total mound volume did not change. So, the extinction or decline of some colonies in the area studied was compensated for by a substantial expansion and spread of existing colonies with large new mounds. F. rufa was the only species that increased in terms of all the population characteristics in 2020 compared to 1990 . The increase in total mound area and volume was relatively limited. As previously shown, the hybrid $F$. rufa $\times$ polyctena was almost extinct. The population characteristics of $F$. pratensis showed a sharp decline of $53 \%-75 \%$.

\section{DISCUSSION}

It can be concluded that changes in the distribution and forest occupation by red wood ants from 1990 to 2020 differed for the different species in this part of Limburg. In this area, F. polyctena decreased slightly in distribution and forest occupancy, $F$. pratensis decreased markedly and $F$. rufa increased. These results are only partially similar to those of the other rather recent long-term studies in Europe mentioned in the introduction. The differences between mono- and polydomous species confirm the previous findings of Mabelis (1994). He reports that the monodomous F. rufa, with one or several queens per nest mound, in dispersing by producing swarms of young queens is better adapted to a fragmented landscape, such as in Limburg. Punttila (1996) reports similar results in Finland for several species of the F. rufa group.

Table 2. Descriptive statistics of the environmental and connectivity variables of the individual forests surveyed in 1990 and 2020 ( $n=82$; SD - standard deviation).

\begin{tabular}{|c|c|c|c|c|c|c|}
\hline Variable & Abbreviation & Minimum & Maximum & Median & Mean & SD \\
\hline Forest area (ha) & FOREST-AREA & 0.04 & 156.78 & 1.78 & 10.99 & 25.99 \\
\hline Lengte of forest edge $(\mathrm{km})$ & FOREST-EDGE & 0.10 & 10.56 & 0.78 & 1.46 & 1.97 \\
\hline Average distance to three nearest neighbouring forests $(\mathrm{m})$ & DIST-FOREST & 9 & 507 & 68 & 105 & 96 \\
\hline $\begin{array}{l}\text { Distance of a forest edge to nearest nest mound } \\
\text { of } F \text {. polyctena (for } 1990 / 2020)(\mathrm{m})\end{array}$ & DIST-MOUND & $15 / 10$ & $2580 / 5100$ & $490 / 650$ & $692 / 1231$ & $680 / 1297$ \\
\hline $\begin{array}{l}\text { Distance of a forest edge to nearest nest mound } \\
\text { of } F \text {. rufa (for 1990/2020) (m) }\end{array}$ & DIST-MOUND & $10 / 10$ & $2070 / 1370$ & $555 / 545$ & $550 / 551$ & $377 / 371$ \\
\hline $\begin{array}{l}\text { Distance of a forest edge to nearest nest mound } \\
\text { of } F \text {. pratensis (for 1990/2020) (m) }\end{array}$ & DIST-MOUND & $40 / 40$ & $3580 / 3600$ & $735 / 1170$ & $938 / 1221$ & $765 / 745$ \\
\hline
\end{tabular}


Table 3. Final models (GLMs), with environmental and connectivity variables as predictors and presence-absence of red wood ants as a response variable $\left[-=\right.$ not selected; ${ }^{*} p<0.05$; ${ }^{* *} p<0.01$; ${ }^{* *} p<0.001$; DF - degrees of freedom; $R^{2}-p s e u d o-R^{2}$ of Nagelkerke; CON - connectivity according to the incidence function model (Hanski,1994); for other abbreviations see Table 2].

\begin{tabular}{|c|c|c|c|c|c|c|c|}
\hline Species - Year & FOREST-EDGE & DIST-FOREST & DIST-MOUND & CON & DF & Nul Deviance & $\mathrm{R}^{2}$ \\
\hline F. polyctena -1990 & - & - & - & $1.24^{*}$ & 81 & 91.11 & $42 \%$ \\
\hline F. polyctena - 2020 & $1.15^{\star *}$ & - & $-0.94^{* *}$ & - & 81 & 83.70 & $64 \%$ \\
\hline F. rufa -1990 & - & - & - & $1.15^{\star *}$ & 81 & 60.81 & $28 \%$ \\
\hline F. rufa -2020 & $1.06^{*}$ & - & - & $2.11^{* * *}$ & 81 & 91.11 & $59 \%$ \\
\hline F. pratensis -1990 & - & - & - & $1.44^{*}$ & 81 & 56.74 & $63 \%$ \\
\hline F. pratensis - 2020 & - & - & - & $2.89^{*}$ & 81 & 31.97 & $72 \%$ \\
\hline
\end{tabular}

For the area studied, the regression models show that high connectivity between forests is important for the presence of species of Formica. The best predictor was the incident function model. In addition, forest edge length also had a positive influence. Such relationships are also reported for patches of $F$. truncorum in the eastern part of The Netherlands (Mabelis \& Chardon, 2006).

The average number of nest mounds per colony for each species is presented in Table 5. They are in line with those of previous studies in Europe (Ellis \& Robinson, 2014). The presented changes in the colony characteristics between 1990 and 2020 broadly support the results and changes in forest occupancy.

For F. rufa, in 2020 more nest mounds were found, but on average, they were smaller. One reason can be that the small ones were recent settlements, which can still grow. It also can be that it is a result of changes in habitat conditions, such as temperature, shading or food quality (e.g., Sorvari \& Hakkarainen, 2005; Juhász et al., 2020), which needs to be investigated further in the area studied.

Several natural or unnatural changes in habitat conditions or populations of red wood ants may occur over a period of 30 years. In this study, the details of the nest mounds were collected in a descriptive way. Some are probable causes of changes in distribution and population development.

Forest edges are important habitats for red wood ants (e.g., Kilpeläinen et al., 2008; DeKoninck et al., 2010). As reported by Mabelis \& Korczyńska (2016), the intensive fertilization of adjacent agricultural land leads to a strong growth of blackberries (Rubus species) and large nettles (Urtica dioica L.) in forest edges in an area. These plants can completely overgrow red wood ant nests. In the case of maize (Zea mays L.) as a crop, it also shades sun exposed forest edges during the summer season. The use of pesticides in agriculture may be an additional problem, as when spread by wind, such substances can penetrate far into woodland and have negative consequences for many insects (Desneux et al., 2007).
In several forests, the forest floor has become strongly shaded over the years. This is due to the closure of the canopy as the trees aged. Stopping small-scale coppicing also led to denser deciduous forests. Moreover, in the forests, there was a marked increase in blackberry, Prunus serotina Ehrh. and eagle fern (Pteridium aquilinum (L.) Kuhn) due to nitrogen pollution via atmospheric deposition (CBS et al., 2019). In the area studied, the growth of tall herbaceous plants and shrubs also took place at locations where conifers were felled or died from attacks by the European spruce bark beetle (Ips typographus L.). The resultant increases in the shading of the forest floor negatively affect red wood ant colonies (Robinson \& Robinson, 2008; Dekoninck et al., 2010; Chen \& Robinson, 2014; Mabelis \& Korczyńska, 2016; Schmitz et al., 2019; Mabelis, 2020; Antonova \& Marinov, 2021).

At some locations in the area studied, incidental events also played a role in the changes in presence. In the north western part, a new motorway was built about 15 years after the first research period, cutting through some small forests with colonies of $F$. polyctena. In advance, the loss in area of forest was compensated for by planting deciduous trees and relocating nests, which was only partially successful.

\section{PROTECTION, MANAGEMENT AND COORDINATION OF RESEARCH}

Under the Dutch Flora and Fauna Act (1998), the red wood ants were legally protected. Nowadays, we have the Nature Conservation Act (2017), which no longer includes the legal protection of species of red wood ants. A so-called duty of care applies, where nest mounds must be protected from disturbance during forest work.

Forest management can have positive and negative effects on red wood ants (Kilpeläinen et al., 2008). This means that good forest management is of importance for the survival, especially in fragmented landscapes. Various felling methods are currently being investigated in

Table 4. The number of nest mounds per location in 1990 and 2020. In parentheses the number of nests surviving from 1990; FOREST - in forest; FEI - forest edge with adjacent intensive agricultural land use; FEE - forest edge with adjacent extensive land use.

\begin{tabular}{|c|c|c|c|c|c|c|}
\hline \multirow{2}{*}{ Species } & \multicolumn{2}{|c|}{ FOREST } & \multicolumn{2}{|c|}{ FEI } & \multicolumn{2}{|c|}{ FEE } \\
\hline & year 1990 & year 2020 & year 1990 & year 2020 & year 1990 & year 2020 \\
\hline F. polyctena & 48 & $47(6)$ & 61 & $30(13)$ & 40 & $36(14)$ \\
\hline F. rufa $\times$ polyctena & 23 & 0 & 20 & $0(0)$ & 4 & $2(2)$ \\
\hline F. pratensis & 21 & $3(1)$ & 40 & $4(0)$ & 11 & $15(8)$ \\
\hline
\end{tabular}


Table 5. Number of colonies, number of nest mounds, nest mound area and volume of nest mounds per species in 1990 and 2020 . In parentheses the percentage difference between 2020 and 1990.

\begin{tabular}{|c|c|c|c|c|c|c|c|c|}
\hline \multirow{2}{*}{ Species } & \multicolumn{2}{|c|}{ Number of colonies } & \multicolumn{2}{|c|}{ Number of nest mounds } & \multicolumn{2}{|c|}{ Total mound area $\left(\mathrm{m}^{2}\right)$} & \multicolumn{2}{|c|}{ Total mound volume $\left(\mathrm{m}^{3}\right)$} \\
\hline & year 1990 & year 2020 & year 1990 & year 2020 & year 1990 & year 2020 & year 1990 & year 2020 \\
\hline F. polyctena & 26 & $17(=-35 \%)$ & 149 & $113(=-24 \%)$ & 116.8 & $91.8(=-21 \%)$ & 29.6 & $29.5(=0 \%)$ \\
\hline F. rufa & 10 & $23(=+130 \%)$ & 12 & $25(=+108 \%)$ & 10.6 & $13.6(=+28 \%)$ & 2.7 & $3.4(=+26 \%)$ \\
\hline F. rufa $\times$ polyctena & 3 & $1(=-67 \%)$ & 47 & $2(=-96 \%)$ & 37.9 & $0.5(=-99 \%)$ & 16.2 & $0.1(=-99 \%)$ \\
\hline F. pratensis & 16 & $4(=-75 \%)$ & 72 & $22(=-69 \%)$ & 29.5 & $13.8(=-53 \%)$ & 4.5 & $1.2(=-73 \%)$ \\
\hline
\end{tabular}

The Netherlands (Den Ouden \& Mohren, 2020; Rabbinge \& Leffelaar, 2020). For red wood ants, a balance must be found between the maintenance of (1) sunlit forest soils, (2) forage trees and (3) connectivity between habitat patches.

In addition, attention must be given to the establishment of buffer zones between intensively used agricultural land and forests, the protection of nest mounds from disturbance and the collecting of pupae (e.g., Robinson \& Robinson, 2008; Dekoninck et al., 2010; Mabelis \& Korczyńska, 2016; Vandegehuchte et al., 2017; Mabelis, 2020). The existence of nests should be prolonged for as long as possible by easy-to-implement management measures, such as, annual removal of surrounding shrubs or invasive herbaceous plants. This kind of knowledge is well known, but not widely applied in the field. Forest owners often pay too little attention or spend little money on species-oriented management for red wood ants. Both aspects apply in Limburg, where private owners, municipalities or nature conservation parties own the forests and forest fragments. It is recommended that a joint long-term maintenance plan is developed.

Early studies in The Netherlands and Belgium and the present research show that at least at the local or regional level, the survival of $F$. polyctena, F. rufa and F. pratensis in strongly managed landscapes is under intense pressure. F. pratensis is also declining in several other countries in Europe (Çamlitepe \& Aksoy, 2019). Therefore, it would be helpful to know the trends in the status of potentially endangered species in the Formica rufa group on a European scale, which could be achieved by specific monitoring. Citizen science can be used for such large-scale studies (Sorvari, 2021). For comparability, a similar inventory method must be used in all years and areas to be surveyed. Furthermore, several challenges and pitfalls must be overcome in order to interpret changes (Berberich et al., 2016; Didham et al., 2020). By analysing data on red wood ants on a large scale, possible general causes of trends can be found and specific improvement measures can be proposed in the future.

ACKNOWLEDGEMENTS. I thank A.A. Mabelis and anonymous reviewers for supplying useful literature and their suggestions on earlier versions of this manuscript.

\section{REFERENCES}

Antonova V. \& Marinov M.P. 2021: Red wood ants in Bulgaria: distribution and density related to habitat characteristics. $-J$. Hymenopt. Res. 85: 135-159.
Berberich G.M., Dormann C.F., Klimetzek D., Berberich M.B., SANDERS N.J. \& ElLISON A.M. 2016: Detection probabilities for sessile organisms. - Ecosphere 7: e1546, 13 pp.

BIS NederLand 2021: Soil Information System Netherlands. URL: http://maps.bodemdata.nl/bodemdatanl/index.jsp [in Dutch].

Boer P. 2010: Ants of the Benelux. Stichting Jeugdbondsuitgeverij, s-Graveland, 183 pp. [in Dutch].

Boer P., NoordiJK J. \& VAN LoOn A.J. 2018: Ecological Atlas of Dutch Ants (Hymenoptera, Formicidae). EIS Kenniscentrum Insecten en andere ongewervelden, Leiden, 125 pp. [in Dutch; English abstract].

Burnham K.P. \& Anderson D.R. 2004: Multimodel inference. Understanding AIC and BIC in model selection. - Sociol. Meth. Res. 33: 261-304.

ÇAmlitepe Y. \& Aksoy V. 2019: Distribution and conservation status of the European red wood ant species Formica pratensis. - J. Entomol. Res. Soc. 21: 199-211.

CBS, PBL, RIVM \& WUR 2019: Nitrogen Deposition 19902018 (indicator 0189, version 18, 21 November 2019). URL: https://www.clo.nl/indicatoren/n10189-stikstofdepositie [in Dutch].

Chen Y.-H. \& Robinson E.J.H. 2014: The relationship between canopy cover and colony size of the wood ant Formica lugubris - Implications for the thermal effects on a keystone ant species. - PLOS ONE 9(12): e116113, 18 pp.

Coenen F. 2006: Montfort Castle Dominates its Landscape. In Coenen F., Gerats R., Hermans J., de Mars H., Ovaa A., Segers M., Smeets J., Staal E. \& Verhart L. (eds): Montfort, a Castle and its Landscape. Stichting het Limburgs Landschap, Lomm/ Stichting Kasteel Montfort, Montfort, pp. 72-91 [in Dutch].

Dekoninck W., Hendrickx F., Grootaert P. \& Maelfait J.-P. 2010: Present conservation status of red wood ants in northwestern Belgium: Worse than previously, but not a lost cause. —Eur. J. Entomol. 107: 209-218.

Desneux N., Decourtye A. \& Delpuech J.-M. 2007: The sublethal effects of pesticides on beneficial arthropods. - Annu. Rev. Entomol. 52: 81-106.

Didham R.K., Basset Y., Collins C.M., Leather S.R., Littlewood N.A., Menz M.H.M., Müller J., PACKer L., SAunders M.E., SCHÖNROGGE K. ET AL. 2020: Interpreting insect declines: seven challenges and a way forward. - Insect Conserv. Divers. 13: 103-114.

Ellis S. \& Robinson E.J.H. 2014: Polydomy in red wood ants. Insectes Soc. 61: 111-122.

Ellis S., Procter D.S., Buckham-Bonnett P. \& Robinson E.J.H. 2017: Inferring polydomy: a review of functional, spatial and genetic methods for identifying colony boundaries. - Insectes Soc. 64: 19-37.

Erisman J.-W., Dammers E., Van Damme M., Soudzilovskaia N. \& SchaAp M. 2015: Trends in EU nitrogen deposition and impacts on ecosystems. - EM: Air and Waste Manag. Assoc. Mag. Environ. Manag. 65: 31-35. 
Goropashnaya A.V., Fedorov V.B. \& Pamiloc P. 2004: Recent speciation in the Formica rufa group ants (Hymenoptera, Formicidae): inference from mitochondrial DNA phylogeny. Mol. Phylogenet. Evol. 32: 198-206.

Gösswald K. 1989: Die Waldameise. Band 1, Biologische Grundlagen, Ökologie und Verhalten. - Aula-Verlag, Wiesbaden, $660 \mathrm{pp}$.

Hallmann C.A., Sorg M., Jongejans E., Siepel H., Hofland N., Schwan H., Stenmans W. , Müller A., Sumser H., Hörren T. ET AL. 2017: More than 75 percent decline over 27 years in total flying insect biomass in protected areas. - PLOS ONE 12(10): e0185809, $21 \mathrm{pp}$.

HANSKI I. 1994: A practical model of metapopulation dynamics. - J. Anim. Ecol. 63: 151-162.

Jactel H., Imler J.-L., LAmbrechts L., Failloux A.-B., Lebreton J.D., Le Maho Y., Duplessy J.-C., Cossart P. \& Grandcolas P. 2020: Insect decline: immediate action is needed. $-C$. $R$. Biol. 343: 267-293.

Juhász O., Bátori Z., Trigos-Peral G., Lörinczi G., Módra G., Bóni I., Kiss P.J., Aguilon D.J., Tenyér A. \& MaÁK I. 2020: Large- and small-scale environmental factors drive distributions of ant mound size across a latitudinal gradient. - Insects 11: $350,11 \mathrm{pp}$

Kilpeläinen J., Punttila P., Finér L., Niemelä P., Domisch T., Jurgensen M., Neuvonen S., Ohashi M., Risch A. \& Sundström L. 2008: Distribution of ant species and mounds (Formica) in different-aged managed spruce stands in eastern Finland. $-J$. Appl. Entomol. 132: 315-325.

LeEst A. van Der, van den MuncKhof P. \& STAM H. (eds) 2006 Large Historical Topographical Atlas of Limburg $\pm 1894-1926$. Uitgeverij Nieuwland, Tilburg, 19 pp. + Maps [in Dutch].

Mabelis A.A. 1994: Flying as a survival strategy for wood ants in a fragmented landscape (Hymenoptera, Formicidae). Memorab. Zool. 48: 147-170.

Mabelis A.A. 2002: Usefulness of Ants for Monitoring Nature Reserves. Alterra-Rapport 571. Alterra, Wageningen, 95 pp. [in Dutch].

Mabelis A.A. 2020: Red wood ants in the pinch. - Vakblad Natuur Bos Landschap 165: 18-22 [in Dutch].

Mabelis A.A. \& Chardon J.P. 2006: Survival of the trunk ant (Formica truncorum Fabricius, 1804; Hymenoptera: Formicidae) in a fragmented habitat. - Myrmecol. Nachr. 9: 1-11.

Mabelis A.A. \& KorcZyŃsKa J. 2016: Long term impact of agriculture on the survival of wood ants of the Formica rufa group (Formicidae). - J. Insect Conserv. 20: 621-628.

NAGELKERKE N.J.D. 1991: A note on the general definition of the coefficient of determination. - Biometrika 78: 691-692.

Ouden J. DEN \& MoHren G.M.J. 2020: The Ecological Aspects of Plain Felling in the Dutch Forest: Report for the Ministry of Agriculture, Nature and Food Security in the Context of the Forest Strategy. Wageningen University \& Research, Wageningen, 63 pp. [in Dutch].

PuntTila P. 1996: Succession, forest fragmentation, and the distribution of wood ants. - Oikos 75: 291-298.
RabBinge R. \& LeFFelaAR P.A. 2020: Ecological Effects of Plain Felling on the Quality of Forest Ecosystems. Stichting NatuurAlert Nederland, Haarlem, 66 pp. [in Dutch].

R Core Team 2021: $R-A$ Language and Environment for Statistical Computing. R Foundation for Statistical Computing, Vienna, URL: https://www.R-project.org/.

Robinson N.A \& Robinson E.J.H. 2008: The population of the red wood ant Formica rufa L. (Hymenoptera: Formicidae) at Gait Barrows National Nature Reserve, Lancashire, England over the 20 year period 1986-2006: nest longevity, reproduction and the effect of management. - Br. J. Entomol. Nat. Hist. 21: $225-241$.

SÁnchez-Bayoa F. \& Wyckhuys K.A.G. 2019: Worldwide decline of the entomofauna: A review of its drivers. - Biol. Conserv. 232: 8-27.

Schmitz A., Sanders T.G.M., Boltea A., Bussotti F., Dirnböck Th., Johnson J., Peñuelase J., Pollastrini M., Prescher A.-K., SARDANSE J. ET AL. 2019: Responses of forest ecosystems in Europe to decreasing nitrogen deposition. - Environ. Pollut. 244: 980-994.

SeIFERT B. 1991: The phenotypes of the Formica rufa complex in East Germany. - Abh. Ber. Naturkundemus. Görlitz 65: 1-27.

SEIFERT B. 1996: Ameisen: Beobachten, bestimmen. Naturbuch Verlag, Augsburg, $351 \mathrm{pp}$.

Seifert B., Kulmuni J. \& Pamilo P. 2010: Independent hybrid populations of Formica polyctena $\times$ rufa wood ants (Hymenoptera: Formicidae) abound under conditions of forest fragmentation. - Evol. Ecol. 24: 1219-1237.

SORVARI J. 2021: Distribution of Finnish mound-building Formica ants (Hymenoptera: Formicidae) based on using a citizen science approach. - Eur. J. Entomol. 118: 57-62.

Sorvari J. \& Hakkarainen H. 2005: Deforestation reduces nest mound size and decreases the production of sexual offspring in the wood ant Formica aquilonia. - Ann. Zool. Fenn. 42: 259-267

Vandegehuchte M.L., Wermelinger B., Fraefel M., Baltensweiler A., Düggelin C., Brändli U.-B., Freitag A., BernasCONI C., Cherix D. \& Risch A.C. 2017: Distribution and habitat requirements of red wood ants in Switzerland: implications for conservation. - Biol. Conserv. 212: 366-375.

VÉLE A. \& Modlinger R. 2016: Foraging strategy and food preference of Formica polyctena ants in different habitats and possibilities for their use in forest protection. - Lesnicky Časopis / Forestry Journal 62: 223-228.

Vitikainen E.I.K., Haag-Liautard C. \& Sundström L. 2015: Natal dispersal, mating patterns, and inbreeding in the ant Formica exsecta. - Am. Nat. 186: 716-727.

Wagner D.L., Grames E.M., Forister M.R., Berenbaum M.R. \& STOPAKD D. 2021: Insect decline in the Anthropocene: Death by a thousand cuts. - Proc. Natn. Acad. Sci. U.S.A. 118: e2023989118, 10 pp.

Received September 29, 2021; revised and accepted January 17, 2022 Published online January 31, 2022 